Vol. 17, $n^{\circ} 2 \mid 2013$

Varia

\title{
Women, Violence and Urban Justice in Holland c. 1600-1838
}

\section{Manon van der Heijden}

\section{OpenEdition \\ Journals}

Édition électronique

URL : http://journals.openedition.org/chs/1429

DOI : $10.4000 /$ chs. 1429

ISSN : 1663-4837

Éditeur

Librairie Droz

Édition imprimée

Date de publication : 1 décembre 2013

Pagination : 71-100

ISBN : 978-2-600-01776-3

ISSN : $1422-0857$

Référence électronique

Manon van der Heijden, « Women, Violence and Urban Justice in Holland c. 1600-1838 », Crime, Histoire \& Sociétés / Crime, History \& Societies [En ligne], Vol. 17, n² 2 2013, mis en ligne le 01 décembre 2016, consulté le 19 avril 2019. URL : http://journals.openedition.org/chs/1429 ; DOI : 10.4000/ chs. 1429 


\title{
Women, Violence and Urban Justice in Holland c. 1600-1838
}

\author{
Manon van der Heijden ${ }^{1}$
}

Le présent article, qui traite des femmes, de la violence et de la justice urbaine entre 1600 et 1838, pose que la qualité des données relatives aux types de violence à l'époque moderne est fonction du degré d'accessibilité de la justice. La violence féminine se révèle ainsi davantage dans les archives des tribunaux inférieurs qui étaient compétents pour les bagarres et les agressions dans le voisinage. En Hollande, les voisins avaient à cour de saisir les dispositifs de sanction existants, de sorte que beaucoup d'hommes et de femmes étaient jugés pour violences. L'accessibilité du système judiciaire néerlandais donnait également aux femmes des moyens diversifiés de se défendre contre les violences conjugales. Surtout, la violence était une affaire communautaire et les voisins jouaient un rôle crucial dans les poursuites de la violence domestique ou ordinaire.

This article about women, violence and urban justice in Holland 16001838 argues that the nature of justice available strongly affects the evidence available about patterns of early modern violence. Women's violence becomes more apparent in the records of the lower courts which particularly handled fights and aggression within neighbourhoods. In Holland neighbours were eager to make use of accessible correction procedures, and that resulted in high numbers of men and women being tried for violence. The accessible Dutch judicial system also gave women a variety of options to defend themselves against domestic violence. Above all, violence was a communal matter, and neighbours played a vital role in the prosecution of both public and domestic violence.

\section{INTRODUCTION: VIOLENCE AND GENDER}

Historians and criminologists working on the subject of violence generally focus on male behaviour, assuming for a number of reasons that women are much less violent than men. Despite the recent interest in neurobiological

1 Manon van der Heijden is a professor of Comparative Urban History at Leiden University (The Netherlands). She is interested in the history of criminal justice, the family, urban finances and public services. In 1998 she received her Ph.D. on marriage before the courts in Holland (1550-1700) at the Erasmus University Rotterdam. She recently published Civic Duty. Public Services of the Early Modern Low Countries (Newcastle, 2012). In 2012 the Dutch Scientific Organization (NWO) granted her a VICI project for excellent scholars, Crime and Gender 1660-1900 [www.crimeandgender. nl]. 
explanations, most social and historical sciences continue to focus on the social learning of gender roles and the impact of such processes on gendered crime patterns. Historians and criminologists generally link gendered patterns in crime to differences in the public lives led by men and women. According to this line of reasoning, women are less likely than men to commit crimes, particularly violent crimes, because they are more confined to the domestic sphere while men have more freedom to engage in public activity. In addition, scholars generally assume that women tend to be victims, rather than perpetrators, of violent crime. ${ }^{2}$ As a result, studies of early modern violence seldom focus on the subject of female interpersonal violence. Most of the studies that do pay attention to female violence in the past focus either on typical female offences, such as infanticide, or on cases related to the sexual honour of women. ${ }^{3}$ In her book on crime and gender in early modern England, Garthine Walker concluded that as historians label such offenses as peculiarly 'feminine', all other offences are implicitly defined as 'masculine'. She rightfully emphasizes that in fact women participated in most categories of crime, and that they were far more likely to participate in non-'feminine' offences. ${ }^{4}$

This article aims to contribute to the discussion about peculiarly 'female' crimes by shifting the attention from male violent behaviour to the violent conduct of both men and women, and to people's responses to that violence in Holland in the period 1600-1838. It covers three distinct but inter-related topics: women's violence, women's prosecutions of men for domestic violence, and the role of neighbourhoods in early modern justice and, in doing so, offers a new perspective on the relationship between gender and violence in Holland from the seventeenth to the early nineteenth century. In his article "How violent are women ?" criminal justice historian Pieter Spierenburg concluded that Dutch women were no fighters. He found that between 1650 and 1750, the Amsterdam court only prosecuted a few women for violence and a fair number of them were charged with trivial acts. The low figures for female violence in Amsterdam are in line with the findings of other historians. ${ }^{5}$

In response to the emphasis of historians on differentiating women's crimes from men's crimes, Trevor Dean has argued that the tendency of historians to stress stereotypical differences between men and women disregards the similarities between the crimes committed by men and women. Instead of emphasising a differentiation based on the specific roles of women and men, he suggests that historians should look at the variety of similar motives that exist for both sexes. ${ }^{6}$ Furthermore, Dean argues strongly for a new direction in the research on women's criminality: one which does not take women's confined position in work and family as a starting point, but instead considers the variety of activities and work opportunities that women did have. He advocates a more flexible notion of gender, a multi-dimensional

For instance: Greenshields (1987); Spierenburg (2008).

3 In his recent book on the history of murder Pieter Spierenburg devotes a chapter to women's roles, although he focuses on women as victims of domestic violence: Spierenburg (2008). Those studies focusing on gender and crime generally deal with typically female crimes, such as sexual offenses, and infanticide. Notable exceptions are Feeley (1994); Arnot, Usborne (2003); Walker (2003); HurlEamon (2005); Dinges (1992); Eibach (2000).

Walker (2003, p. 4).

5 Hanawalt (1979, p. 123); Heijden (1995, pp. 4-7); Spierenburg (1997, 2008, pp. 117-122); Eisner (2003, pp. 118-119).

6 Dean (2008, p. 400); Walker (1994, p. 65); Morris (1987, pp. 81-91). 
spectrum rather than a binary divide, in which different male and female behaviour are represented "alongside a broad band of shared, similar behaviours". ${ }^{7}$

Warner and her co-authors came to similar conclusions in their examination of violence in Portsmouth in the years 1653-1781. They found that women accounted for just over 31 per cent of all recorded assaults, and there were very few differences between the fighting styles of men and women. For Scotland between 1750 and 1815, Anne-Marie Kilday also concluded that female violence that came before the Scottish Justiciary court was more bloody and brutal than historians commonly assume. ${ }^{8}$ Similar conclusions are drawn by Jennine Hurl-Eamon in her book on petty violence in London, 1680-1720. She found that women could become very assertive and aggressive in particular instances, though the violence of women was generally a result of more immediate neighbourhood tensions. The London accounts made it clear that both sexes were inclined to deploy violence. ${ }^{9}$

A more nuanced approach which combines both a quantitative and qualitative analysis is needed to explain gender differences in violence in the early modern period and how such violence was dealt with through both legal and extrajudicial means. The concept of "The Uses of Justice" as introduced by Martin Dinges may be a very useful approach for explaining gender differences in the indictment of aggressive behaviour. Following Robert Shoemaker in his work on prosecution and punishment, Dinges proposes that historians should focus on the ways in which and the extent to which people had recourse to justice in order to explain patterns of prosecution. ${ }^{10}$ To use the words of Dinges: "People would have used the institutions of justice merely as an additional instrument of everyday social control, not dissimilar to an admonition or a form, even a violent form, of self-help". The uses of justice therefore refer to the many ways in which individuals dealt with the courts, the recourse to justice, and the forms that this took. ${ }^{11}$

The concept of the uses of justice is highly relevant to the case of early modern Holland. Dinges mentions the Dutch tradition of extrajudicial settlements within local (mostly urban) civic and religious institutions, such as the neighbourhoods, church communities, and guilds. These forms of conflict regulation existed alongside various judicial procedures which people could use to settle a dispute or to find justice. ${ }^{12}$ The comparison of criminal justice and church discipline in early modern Holland reveals that people played an active role in both the prosecution and reconciliation process. They also understood how to make use of the institutions as a means of resolving their private and public problems. ${ }^{13}$

I will argue that the numbers and proportion of violent acts by women found in the criminal court records offer only a partial view of women's violence in everyday life. Different types of courts and judicial procedures may produce different figures and proportions of male and female violence, because such figures were determined by how frequently and in what ways these courts were used by people. I am not

\footnotetext{
Dean (2008, p. 412).

Warner, Graham, Adlaf (2005); Kilday (2007).

Hurl-Eamon (2005, pp. 11 \& 128).

Dinges (2004, pp. 159-161); Shoemaker (1991).

Dinges (2004, p. 160).

Dinges (2004, p. 161); Heijden (2012, pp. 94-101).

Heijden (2004, p. 75).
} 
disputing the data shown by Spierenburg; the Amsterdam criminal court without a doubt did prosecute few women. My argument is that there is also information about violence to be found in other judicial procedures that have rarely been looked at. ${ }^{14}$ By looking at different types of courts and procedures of conflict settlement, historians will have a much better overview of the violence committed by men and women, and the ways in which people could defend themselves against violence.

There are two important reasons why the case of the Netherlands is highly relevant when examining violent behaviour in early modern urban neighbourhoods. Firstly, in early modern societies, there was a strong link between urbanisation and high levels of female crime rates. As the most urbanised region in Europe in the seventeenth and eighteenth centuries, the Low Countries provide ample urban sources for examining the patterns of male and female violent behaviour. Secondly, in most Dutch towns neighbours and neighbourhood organisations played a vital role in the social control of violence and aggressive behaviour, and through a study of their actions we can gain a deeper understanding both of violence and attitudes towards it.

What do we mean by violence? Most current dictionaries distinguish between two forms of violence: physical violence and verbal violence. The first refers to "physical force exerted for the purpose of violating, damaging, or abusing", while the latter refers to "great strength of feeling, as in language". ${ }^{15}$ Early modern historians often use a rather broad definition of violence, including verbal injury, scolding and other words intended to hurt. In his article about women's violence, Spierenburg prefers to exclude verbal violence because his main interest is in serious violence, and consequently his examinations focus on the records of the regular Amsterdam criminal courts, rather than lower tribunals dealing with minor conflicts. Gerd Schwerhoff on the other hand, argues that historians should include all forms of violence in order to understand how and why people had violent disputes. Violence may be seen as an act of aggression that was prosecuted by the courts, but it can also be seen as a means of communication among people. Violence is not only the object of social control, but just as much a medium for social control. Schwerhoff's main argument is that understanding violence implies a 'thick description' of violent behaviour as well as categorising changes in the reasons, forms and intensity of violence in history. ${ }^{16}$ This article focuses on the narrow definition of violence physical force - because I want to compare women's share in violence in different types of courts in order to show that such a comparison reveals a much higher rate of female physical violence than has commonly been found by historians.

I begin with a description of the figures found in the records of the urban criminal courts in Holland. I then consider the ways in which neighbours and spouses could use the judicial system in order to control violence. I then turn to the rates of women's violence found in the lower judicial institutions in Holland. Finally, I link the social control of violence to the degree of urbanisation and the uses of justice.

\footnotetext{
14 See also: Muchembled (2012, p. 36); Hurl Eamon (2005, p. 11).

15 [http ://www.thefreedictionary.com/violence] (January 2013).

16 Schwerhoff (2004, p. 223).
} 


\section{THE USES OF JUSTICE}

The findings of this article are based on sources from various towns in Holland in the period between 1550 and 1838 : records of the criminal courts and correctional courts ; records of confinement on request (people could submit a request to aldermen in order to put a disorderly family member in a house of correction); records of the consistories of the Reformed Church, and records of neighbourhood organisations. ${ }^{17}$

Clearly, different types of courts - lower and higher, local and central, urban and rural, criminal and civil - handled different types of crime and had different kinds of procedures. Moreover, the number and types of cases handled by different types of courts were determined by the ways in which city dwellers made use of procedures of conflict regulation. Early modern prosecutors largely depended on the willingness of victims to report misdemeanours and aggressive behaviour. ${ }^{18}$ Indeed, various French, English and German studies have shown that for the early modern period violence is not so much found in the classic judicial sources, such as the criminal courts of towns, but rather in less well examined sources. Muchembled argues that in France the classic judicial sources suggest a much lower rate of homicidal violence than the letters de remissions. And for early modern London, Hurl-Eamon showed that prosecution and perpetration of petty violence was found particularly in certain legal procedures, such as the recognizances. ${ }^{19}$

The prosecution of male and female violence by the courts also depended on the courts' willingness to support battered spouses in their cases. Joachim Eibach and Schwerhoff have argued that early modern justice was an instrument of conflict regulation as well as an agent of moral discipline. ${ }^{20}$ To what extent did courts and consistories support the dominance of husbands and fathers in the household ? Eibach found for eighteenth-century Frankfurt that men's dominant behaviour was just as much controlled in the sense that women brought violence to the marriage courts and women were supported by the court. ${ }^{21}$ In line with Eibach's findings, Rebekka Habermas concluded that the criminal courts of Frankfurt supported women against domestic violence, although they increasingly became an instrument of urban moral policies. ${ }^{22}$

As Susanna Burghartz found for early modern Basel, recourse to justice and the strategies of the courts were not static elements, but subject to change. Over the course of the period 1536-1689, the marriage court of Basel shifted from a forum directed at conflict regulation between husbands and wives to an institution that was

17 The information on the criminal court records and the consistories of Delft and Rotterdam are based on my own research: City Archive Rotterdam, Criminele Sententieboeken, Examenboeken, Besoingeboeken, Correctieboeken (Quade Clap) (1550-1800), Consistory notes of the Dutch Protestant Church (1639-1700); City Archive Delft, Criminele boeken, Confessieboeken (1550-1700), Consistory notes of the Dutch Protestant Church (1573-1700). The data from Amsterdam and Leiden are primarily based on the secondary work of others, particularly: Kloek (1990); Pol (1996); Meeteren (2006); Ruitenbeek (2010).

18 Farge (1986, 1993); Castan (1980); Garnot (2000, pp. 131-139); Shoemaker (1991); Heijden (2012, pp. 94-100).

19 Muchembled (2012, p. 36); Hurl-Eamon (2005, p. 124).

20 Schwerhoff (2004, p. 223); Eibach (2007, p. 173).

21 Habermas (1992); See also: Eibach (2007, p. 186).

22 Eibach (2007, p. 171). 
aimed at the disciplining of all irregular sexual behaviour. ${ }^{23}$ Professionalization of police forces and judicial systems may have changed prosecution policies of towns and the role of citizens in the course of the early modern period, though Catherine Denys emphasizes that in most European towns infra-juridical mechanisms remained important. At the end of the eighteenth century inhabitants of a district or a neighbourhood were still vital in the prosecution of crime. ${ }^{24}$

The idea of 'the uses of justice' was noticeable in the different institutions of social control existing in the towns of Holland. City dwellers were very aware that they could use legal and semi-legal procedures as a means of taking measures against deviant or undesirable behaviour. The uses of justice and semi-legal procedures of correction thus had an influence on the number and proportion of cases of male and female violent behaviour. Women's crimes were more likely to be handled by lower courts or less informal methods of dispute regulation than by higher courts, such as the London Old Bailey, which handled more serious crimes. The criminal courts of most towns in Holland also dealt with less serious cases of violence, although complaints and accusations regarding fighting and lesser forms of violence were sometimes handled in the books of correction (in which petty crime was recorded). However, these formal procedures were usually the last step that people took to control the violence of spouses or neighbours. They preferred first to try to use less formal and easier procedures, such as conflict regulation through a neighbourhood master, church discipline by the Protestant consistories, or a request to the magistrates to confine an abusive relative. ${ }^{25}$

\section{VIOLENCE BEFORE THE CRIMINAL COURTS}

Following Manuel Eisner on European homicide and assault, Spierenburg has argued that women's involvement in serious violence was rather stable from the middle ages until the twentieth century. Spierenburg explains: "The normal range of female perpetrators - of homicide, assault, and robbery combined - lay between 5 and 12 percent. The approximate upper limit was 15 percent". ${ }^{26}$ These figures represent women's actual violence, although moral and legal norms about the behaviour of men and women may have led to biased prosecution policies. Although women were also accused of violent offences, they were less likely to be arrested and were treated more leniently by the judges.

This general picture is confirmed by the criminal court records of the towns of Holland. The criminal courts handled crimes that were prosecuted by the bailiff as public prosecutor, involving a judicial procedure with examinations of the defendants, complainants, and witnesses, a sentence demanded by the prosecutor, and a final sentence by the members of the court (aldermen). The violence treated by the criminal courts of Holland - primarily homicide, rape, assault, fighting with knives, and violations of property - predominantly involved men. In the period between 1650 and 1750, approximately 6 to 16 percent of the assault cases handled

\footnotetext{
Burghartz (1999, pp. 127-131).

24 Denys (2010).

25 Heijden (2004); Meeteren (2006); Bekker (2012).

26 Eisner (2003); Spierenburg (2008, p. 117).
} 
by the criminal courts of Amsterdam, Leiden and Rotterdam - the three most important towns in Holland - involved women. The table relating to the proportion of female defendants in assault cases in the towns of Holland shows that the highest figures were found in Amsterdam; between 1651 and 1716, women's share in violence was 13 to 16 percent. The data on Leiden and Rotterdam in the seventeenth and eighteenth centuries show figures of women's violence that were lower than 12 percent. ${ }^{27}$

Spierenburg concludes that his findings regarding women committing nonhomicidal violence show indisputably that women were not fighters, and those of them who were violent belonged to the lower echelons of the lower middle class and only attacked other women. Spierenburg suggests that the chief explanation for the low level of female violence is to be found in the unequal balance of power between men and women, defining violence as a function of this balance of power. ${ }^{28}$ Although recognising that men's greater physical strength in part explained the female patterns of violent behaviour, he concludes: "The culture of violence was a male culture and women recognized that". ${ }^{29}$

Table 1. The proportion of female defendants in assault cases before the criminal courts in the towns of Holland, ca. 1650-1750

\begin{tabular}{|l|l|l|l|}
\hline Period & Amsterdam $^{30}$ & Leiden & Rotterdam \\
\hline & & & \\
\hline $1651-1683$ & $13 \%$ & & \\
\hline $1684-1716$ & $16 \%$ & & \\
\hline $1678-1794$ & & $12 \%$ & \\
\hline $1717-1749$ & $6 \%$ & & \\
\hline $1700-1750$ & & & $6 \%$ \\
\hline
\end{tabular}

Sources: Kloek (1990, p.146); Spierenburg (1997, p.17); Oude Rechterlijke Archieven Rotterdam, Sentences of the Criminal Court (Sententieboeken) 1700-1750, inv.nrs. 252-255. ${ }^{30}$

The data of criminal court records of the towns of Holland in the seventeenth and eighteenth centuries appear to confirm the stereotypical image of the unequal balance of power between men and women. In Rotterdam and Delft, in the period between 1550 and 1700, women stood accused in only 4 percent of the criminal court cases involving domestic violence; in contrast, 96 percent of domestic violence was committed by husbands. The domestic violence of husbands against their wives could be quite severe. Those men who were indicted by the criminal courts of Rotterdam and Delft between 1550 and 1700 were often drunk when maltreating their wives, sometimes using a knife or sword and causing serious injuries. Roughly 50 percent

\footnotetext{
$27 \quad$ Kloek (1990); Heijden (1995).

28 Spierenburg (1997, p. 13).

29 Spierenburg (1997, p. 27).

30 The court cases of Amsterdam (a sample of 3 periods in the period of 1650-1750) did not include homicide; only $8 \%$ of the prosecuted killers were women: Spierenburg (1997, pp. 9-28 \& 17).
} 
of the criminal court cases involving domestic violence were accompanied by excessive drinking (usually brandy). ${ }^{31}$

In cases of maltreatment by their husbands, women had recourse to the legal process and some of them used this right by bringing an abusive husband to court. ${ }^{32}$ However, such cases were few, probably because many wives were afraid of the consequences of a sentence by the criminal court. Their husbands might be banished or sentenced to prison for a long period of time, which would have serious consequences for the family income. In fact, men tried before the criminal and correctional courts for domestic violence were frequently supported by their wives who attempted to have their husbands released from prison. Women were even willing to support a husband after a cruel assault and serious injuries resulting from knife stabbing. ${ }^{33}$

The violence that came before the criminal courts pertained to severe violence involving injuries and wounds, and the data shows that such cases predominantly involved men, and rarely women. However, it would be wrong to assume that women in this period were not violent. As the following paragraphs will show, women were also often prosecuted for aggressive behaviour, although their cases were more likely to be handled by the lower criminal courts, which usually dealt with less serious offences. Furthermore, the data of the criminal court cases appears to reflect the unequal balance of power between men and women, although it would be wrong to assume that Dutch women had no power and no means to defend themselves against male violence.

There are reasons, in fact, to argue the opposite. The accusations against violent husbands also reveal that despite the fact that women were legally subject to their husband's authority, wife-beating was not tolerated and wives and neighbours took measures against domestic violence. ${ }^{34}$ In what ways did neighbours and neighbourhood organisations support and protect battered wives against their violent husbands?

\section{NEIGHBOURS' INVOLVEMENT}

In early modern Dutch towns, neighbourhoods were important social and cultural networks which created social cohesion among citizens and played an important role in the social control of violence. As in Italy, southern Germany and France, neighbourhood organisations emerged in the Netherlands in the fifteenth and sixteenth centuries, often organised as administrative units or corporations, with neighbourhood masters or deans functioning as heads. ${ }^{35}$

The neighbourhoods were rather small entities, representing only a number of inhabitants from a single street or at most a number of streets. In the course of the early modern period, the growth of cities in Holland resulted in the growth of the

\footnotetext{
31 Heijden (1998, pp. 169-176).

32 Heijden ((2000, pp. 633-635).

33 Heijden (1998, pp. 169-176, 2000).

34 See also Farge $(1980,1993)$.

35 Descimon, Nagle (1979); Garrioch (1986); Garrioch, Peel (2006); Lis, Soly (1993); Rostenthal (2006); Burke (2006); Hoffmann (2004, 1999).
} 
number and significance of neighbourhood organisations. In 1581, there were 73 neighbourhood masters in the town of Leiden, while in 1675, their number was as high as 208. Between 1602 and 1624, the father of famous Dutch painter Rembrandt was one of them. The functions and purposes of the neighbourhood masters were twofold: they were significant keepers of the peace in their own locality, but they also had an important task as intermediaries between the urban government and the citizens of their locality. ${ }^{36}$ Surprisingly, only a few Dutch scholars acknowledge the vital role of the neighbourhood corporations in many civic matters. ${ }^{37}$

Not all towns had neighbourhoods that administered communal activities among citizens, or neighbourhood organisations that offered forms of conflict regulation and social and financial support. No records have been found in Amsterdam proving that the neighbourhood corporations really did exist there, but there is evidence that the urban government planned to divide the city into neighbourhood entities. ${ }^{38}$

In many other Dutch towns, such as the textile centre of Leiden, the sea-faring town of Rotterdam and the town of Utrecht, neighbourhood organisations served as the most informal level of conflict regulation and public order. On some occasions neighbourhood corporations might have served as night guards. ${ }^{39}$ Neighbourhood masters acted as peacekeepers and intermediaries between quarrelling locals, and they had the power to impose fines if inhabitants did not obey or endorse the neighbourhood customs and rules. Measures were taken to deal with all kinds of irregular behaviour. In Leiden, citizens might be fined for beating a spouse or for continuous quarrelling or fighting with neighbours. ${ }^{40}$ Neighbourhood corporations offered city dwellers a forum through which they could, at least to some extent, influence legal decision-making. ${ }^{41}$

The first step which neighbours could take against the violent behaviour of their fellow neighbours was a complaint to the neighbourhood master who could reprimand the perpetrator for improper behaviour. In some towns, as in Leiden, neighbourhood rules were established, which included instructions for neighbourhood masters in cases of violence, fights or disorder. There were standard fines for beating your spouse; wife-beaters had to pay a ham (piece of pork) of 15 pounds or a fine of 2.5 guilders, while husband-beaters were fined twice as much. The double standards may suggest that in cases of domestic violence women were less well off than men, although in practice such regulations primarily protected women. The records of the neighbourhoods of Leiden show that fines for spouse-beating were imposed on wifebeaters, while such fines were seldom imposed on wives. ${ }^{42}$

If the intervention of the neighbourhood master did not result in the improvement of a husband's behaviour, neighbours could - led by the neighbourhood master start a procedure before the peacemaker's court. In such judicial procedures the neighbourhood master played an intermediary role between the institutions and the

For studies on the Low Countries: Walle (2005); Roodenburg (1992); Dorren (1998); Meeteren (2006); Bogaers (2008); Deceulaer (2009).

37 Heijden (2012, pp. 65-69).

38 Frijhoff, Prak (Eds) (2004, p. 229); Kuipers (2005, pp. 303-305).

39 Deceulaer (2009, p. 207).

40 Walle (2005, pp. 44-49).

41 Deceulaer (2009, pp. 196).

42 Walle (2005, pp. 77-84). 
people from his neighbourhood. In many cases he also acted as a witness for the prosecution. Studies on the Leiden neighbourhoods suggest that the courts often supported a neighbourhood claim against a wife-beater. Furthermore, neighbours' support in such cases made a woman's case much stronger when filing for divorce or when starting a lawsuit or a confinement on request against an abusive husband. ${ }^{43}$

Finally, neighbours could bring cases of domestic violence to the correctional or criminal court and they regularly did so. Where women were plaintiffs in cases of physical abuse by a husband, they were supported by neighbours who were very much involved in matrimonial disputes and maltreatment within the marriage. Violent or drunk husbands were accused by family members or neighbours, or evicted from the house after a confinement on request. ${ }^{44}$ Neighbours intervened particularly when fights between spouses caused disturbance and noise. ${ }^{45}$ The majority of the criminal cases regarding violent behaviour by husbands were initiated and supported by people from the neighbourhood. Neighbours provided substantial evidence in many criminal cases of maltreatment: their statements and witness statements were essential in the examinations. 56-year old Joris van IJperen from Rotterdam was arrested in 1650 because he regularly beat his wife when he was drunk. However, when both his wife and the neighbours agreed to let him go if he promised to improve his behaviour, the court decided to release him. ${ }^{46}$ Obviously, the neighbours had their own interests. Disturbing the peace appeared to be a vital argument in the accusation and conviction of wife-beaters. ${ }^{47}$

\section{THE USES OF JUSTICE AGAINST VIOLENT HUSBANDS}

Neighbours were very supportive when it came to domestic violence against women. The data related to the criminal court records may suggest that women were very reluctant in bringing their husbands to court, but other sources point to a different conclusion. In addition to more serious legal procedures - such as the criminal or correctional court procedures - there were other options for women to seek justice. They could choose to bring their cases to a public notary who recorded their statements about the insulting maltreatment they suffered from their husbands, and such statements could be used to support a lawsuit for divorce or separation. Here, women were supported by the statements of neighbours as well. ${ }^{48}$ In addition, women could request the urban magistrates to confine their husbands in a house of correction which kept persons who were incarcerated at the request of a family member. In many towns, although not everywhere, the petitioners had to pay the town government a fee for the costs of confinement. In towns where there were no costs for the applicants, people made extensive use of confinement on request. Dinges has argued that applicants may have requested the confinement of a relative merely as a way to coerce that abusive person to reform his or her behaviour. The

\footnotetext{
$43 \quad$ Walle (2005, pp. 77-86); Meeteren (2006, pp. 51-59).

44 Heijden (2000); Helmers (2002, p. 140); Groot (1939, pp. 9-13).

45 Haks (1982, pp. 58-59, 153).

46 City Archive Rotterdam, Correctional Court Records (Vechtboeken), nr. 270, 24 January 1650.

47 Heijden (2000, pp. 633-634).

48 Heijden (2000, pp. 633-634); Meeteren (2006, p. 184).
} 
threat to have him or her confined to a place where the inmates were subjected to forced labour, corporal punishment and solitary confinement may have been enough to change a family member's violent behaviour. ${ }^{49}$

Data on confinement on request in various towns in Holland - such as Rotterdam, Leiden and Dordrecht - in the seventeenth and eighteenth centuries reveals that many women were willing to pursue their request to confine an aggressive husband. Around 60 percent of the confinements on request were initiated by women, and generally they cited their husband's drunkenness, violence and mistreatment. ${ }^{50}$ The findings on the confinement requests show that women may have been reluctant to bring their husbands to criminal court; they were much more willing to make use of less rigorous ways of incarcerating a husband. A confinement on request commonly resulted in a confinement of one or two years. Female applicants apparently were able to financially support themselves for several years, although they would not take the risk that their husbands could be sentenced by the criminal courts to a much longer period of banishment or severe corporal punishments. ${ }^{51}$

In addition to a confinement on request, there were other ways to denounce domestic violence. Women could complain to the elders and ministers of the consistories of the Protestant Church, who would reprimand their husband, order him to come to the consistory's chamber to give an account of his behaviour, or they could, in more severe cases, withhold him from the Lord's Supper. ${ }^{52}$ Husbands could do the same. According to the minutes of the consistories of Delft and Rotterdam in the sixteenth and seventeenth centuries, both men and women regularly complained about the fights and maltreatment they suffered at the hands of their spouses, and the spouses in question were ordered in almost equal measure by the ministers to account for their aggressive behaviour.

Table 2: Domestic violence before the criminal courts (1550-1700) and Protestant consistories (1573-1700)

in Rotterdam and Delft, numbers and proportion of those men and women accused.

\begin{tabular}{|l|l|l|l|}
\hline \multicolumn{2}{|c|}{ Criminal Courts } & \multicolumn{2}{c|}{ Consistories } \\
\hline Men & Women & Men & Women \\
\hline $50(96 \%)$ & $2(4 \%)$ & $164(55 \%)$ & $131(44 \%)$ \\
\hline
\end{tabular}

$\mathrm{N}=347$

Sources: City Archive Rotterdam, Criminal Court Records 1550-1700; Records of the Protestant consistory, 1639-1700; City Archive Delft, Criminal Court Records, 1550-1700; Records of the Protestant consistory, 1573-1700.

The number of disciplinary cases recorded in the consistory minutes does not reflect the total of the disciplinary cases because sometimes elders and ministers kept

\footnotetext{
$\overline{49}$ Dinges (2004, pp. 161-164).

50 Bekker (2012, pp. 38-39); Helmers (2002, p. 150); Spierenburg (1991, 1995, pp. 88-112).

51 See also Heijden (2004).

52 Heijden (1998, pp. 169-176).
} 
their disciplinary actions discreet and informal. ${ }^{53}$ What the recorded cases do show are the ways in which maltreatment and fights between spouses were discussed and treated. While women were much less willing to start legal proceedings against their husbands in case of maltreatment, they were much less reluctant to complain about their husband's behaviour to the elders and ministers. The cases of violence that came before the consistories in Holland show that women became more assertive in relation to their husbands in the course of the seventeenth century, or at least they were more often willing to leave the house. The increasing willingness of women to denounce a husband's violent behaviour appeared to reflect a general trend in Holland that started in the second half of the seventeenth century. In the eighteenth century women increasingly made use of confinement on request in order to have their husbands incarcerated. ${ }^{54}$

This more assertive attitude seems to be related to the growing opportunities in the course of the seventeenth and eighteenth centuries for filing for divorce. In the Calvinist Dutch Republic, women and men were able to file for divorce in case of adultery or prolonged desertion. The legalisation of divorce also influenced the existing practice of separation. Until approximately 1650 , the number of separations in the towns of Holland rose, both in an absolute and in a relative sense. ${ }^{55}$ From the end of the seventeenth century on, the number of divorce cases, and particularly separations, increased markedly. ${ }^{56}$ The vast majority of these cases - separations as well as divorces - were filed by women. In Amsterdam in the second half of the eighteenth century, almost 70 percent of the plaintiffs were women. ${ }^{57}$ Obviously, they were more active than men in using these new legal instruments.

From the end of the seventeenth century onwards, lawyers expanded the conditions allowing for divorce..$^{58}$ Lawyers and judges increasingly realised that the dominant legal position of men was not supposed to lead to violations. The most famous among them - Hugo Grotius - argued that men who abused their custody rights over their wives ought to be prosecuted in a civil or criminal court. In the first instance, maltreatment of wives was to be fined, but in case of recidivism, a heavier punishment was required. ${ }^{59}$ Abuse and alcoholism were not officially grounds for divorce, but women could file for separation on the basis of these complaints, and in practice these were the most frequently mentioned grounds. ${ }^{60}$ The possibility and social acceptability of divorce led to a more powerful bargaining position for married women. Divorce was the ultimate solution in a series of options women

53 Ibid. Obviously, the cases recorded reflect only part of the cases that elders and deacons dealt with in their quarters. Pollmann argues that the Dutch Reformed Church kept no record at all of approximately 70 percent of the disciplinary cases that it handled. However, her findings are based on only one journal of one elder of the Reformed Church of Utrecht during a period of only four years (Pollmann, 2002).

54 Heijden (1998, pp. 224-225); Bekker (2012, pp. 41-42).

55 Heijden (1998, pp. 225-226); Haks (1982, p. 196); Joor (1985, pp. 197-230, 213).

56 Helmers (2002, pp. 224-225).

57 Helmers (2002, pp. 206-207,140); requests for confinement in the Amsterdam house of correction were also instigated by wives in 58 percent of cases.

58 Haks (1982, pp. 180-184, 209-210); Joor (1985, p. 208).

59 Heijden (2000); Helmers (2002, p. 140); Groot (1939, pp. 9-13).

60 Helmers (2002, p. 207). 
could choose from when dealing with an abusive husband and, as we saw, they did not have to stand alone in this.

The data of the consistory records reveal the domestic violence of women that was concealed in the records of the criminal courts. Women made up 44 percent of the cases involving violence that were brought before the consistories. This high figure may be explained by the character of church discipline. Without the risk of a conviction or a confinement, both men and women were much more willing to complain about the aggressive behaviour of their spouses. The high numbers of disciplinary cases brought before the consistories involving violent wives can also be explained by considering the definition of violence. The criminal courts dealt primarily with physical violence, while verbal violence and cases of defamation were generally treated by civil courts (and rarely by correctional courts). In the minutes of the consistories, such differences were much less clear because spouses were often accused of various forms of violence. Swearing, foul language and drunkenness were often accompanied by beating, kicking, throwing things or other physical violence. The cases brought before the lower criminal courts may give a much clearer indication of women's violent behaviour, because here the defendants were unambiguously accused of physical violence.

\section{VIOLENT WOMEN BEFORE THE CORRECTIONAL COURTS}

Looking for violent women implies looking for sources which reveal violent female behaviour that may be hidden in records of the most serious violent crimes. Different types of correctional procedures show different proportions of male and female criminality. For the London area between c. 1664 and 1721, Shoemaker found that fewer women were accused of crime at the Middlesex quarter sessions, although women were more than twice as likely to be committed to a house of correction as men. ${ }^{61}$ While the data of the Dutch criminal court records suggest that violence was predominantly a male offence, the records on the courts of correction procedures (which commonly dealt with less serious crime) reveal a totally different picture.

The records of the Rotterdam correction procedure (less serious crime dealt with by the court) - which did not include a regular trial with extensive examinations are also called 'fight books' because the procedure pertained primarily (but not only) to fighting and assault. ${ }^{62}$ To some extent the procedure was similar to the misdemeanour prosecutions before the English summary courts as described by Shoemaker in his work on London and Middlesex between 1660 and $1725 .{ }^{63}$ While defendants convicted by the criminal courts faced a variety of corporal and custodial punishments including whipping, branding, imprisonment in a workhouse, banishment, and hanging, most defendants recorded in the books of correction were only fined or sentenced to a few days or months of confinement (on "water and bread" as the judges called it). Those people who were fined were given the option either to pay a fine or to be committed for a short period of imprisonment.

\footnotetext{
61 Shoemaker (1991, pp. 149, 185).

62 Heijden (1995).

63 Shoemaker (1991).
} 
Table 3

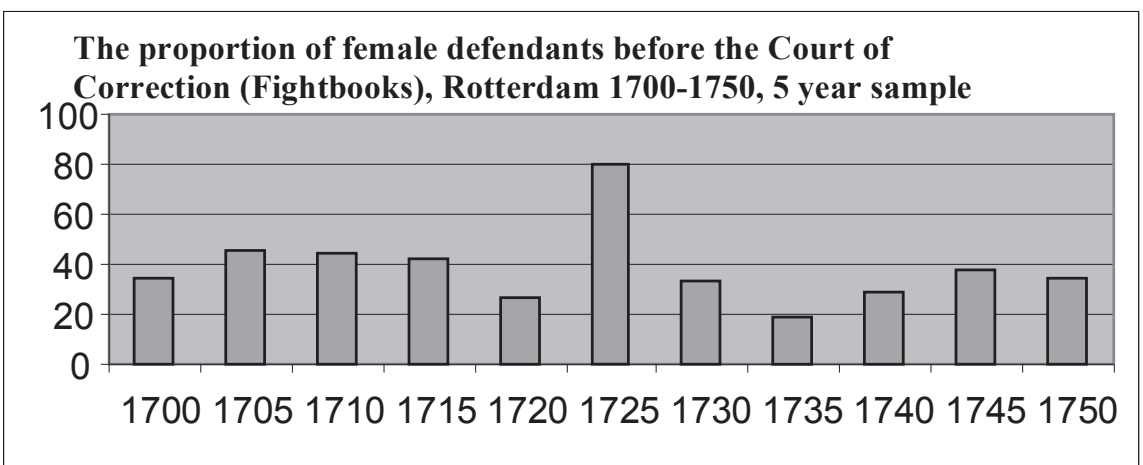

$\mathrm{N}=73,5$ year sample $1700-1750$

Source: City Archive Rotterdam, Old Judicial Archives, Vechtboeken and Quade Clap, 1700-1750, inv. nrs. 267-270.

Table 4: Number and proportion of men and women corrected for violence by the court of correction (fightbooks) Rotterdam, 5-year sample from 1700 to 1750

\begin{tabular}{|l|l|l|}
\hline & Men & Women \\
\hline All cases & $156(68 \%)$ & $73(32 \%)$ \\
\hline Violence & $116(76 \%)$ & $36(24 \%)$ \\
\hline Fighting & $15(58 \%)$ & $11(42 \%)$ \\
\hline
\end{tabular}

$\mathrm{N}=229,5$ year sample $1700-1750$

Source: City Archive Rotterdam, Old Judicial Archives, Vechtboeken and Quade Clap, 1715-1750, inv. nrs. 267-270.

During the period between 1700 and 1750, a mere 6 percent of the violent acts prosecuted by the criminal courts in Rotterdam and Amsterdam involved women. A completely different picture emerges from the cases of violence brought before the court of correction during the same period of time. The proportion of violent women brought before the courts of correction between 1700 and 1750 was significantly higher: almost a quarter of the violence involved women (including fighting with another person and the destruction of property and belongings). Furthermore, women were responsible for 42 percent of the correction cases involving fighting. It may not come as a surprise that women were particularly prosecuted for fighting with and assaulting other women; about 30 percent of the fights involved another woman and usually the fight took place in the neighbourhood. ${ }^{64}$

The proportion of female violent crime as shown in the records of the Rotterdam court of correction was no different in the second half of the eighteenth century.

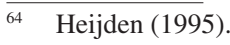


Although the number of men and women who were prosecuted by the court of correction between 1738 and 1795 considerably fluctuated in this period, the proportion of women was quite stable over the years. Between 1750 and 1795, on average 35 percent of the cases brought before the correctional court concerned women. During this period, the judges of the Rotterdam court of correction dealt with 5,954 prosecutions, of which 2,065 involved female crimes. In some years, the female share in violence was much higher still, for instance, during the periods 1769-1771 and 1773-1776, women accounted for 44 percent of misdemeanour prosecutions.

Table 5

\section{Proportion of female defendants before the Rotterdam Court of Correction (Fightbooks), Rotterdam 1738-1795}

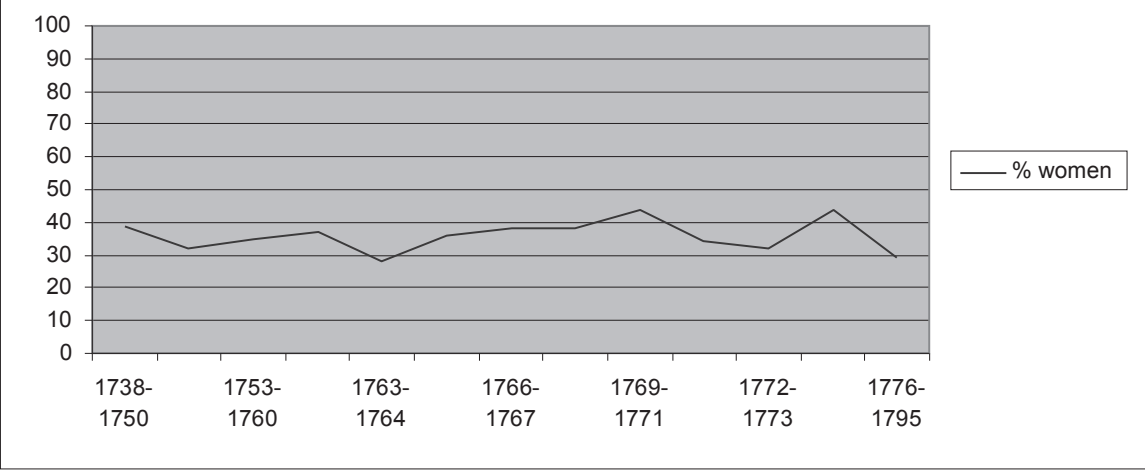

$\mathrm{N}=2065$

Source: Oude Rechterlijke Archieven Rotterdam (ORA), Vechtboeken 1738-1795, inv.nrs. 269-282.

If neighbours were active in bringing the aggressive behaviour of husbands to the criminal courts; they were equally active in bringing female violence to the lower court of correction. In 1750, Lena Flaes was arrested and convicted by the court of Rotterdam after a complaint of the neighbours that she had beaten the daughter of one of her neighbours. Furthermore, men and women received similar punishments for similar violent behaviour. Lena was confined for eight days (on water and bread), just like many men who where arrested for beating a neighbour. ${ }^{65}$ Whether the aggressor was male or female, he or she was generally sentenced to a short imprisonment of eight days to three months at the most. ${ }^{66}$ The assumption that prosecutors treated women with more leniency, particularly with respect to their violent behaviour, clearly does not apply to the cases treated by the Rotterdam court of correction in the eighteenth century.

65 City Archive Rotterdam, Correctional Court Records, nr. 270, 1750-1753.

66 Heijden (1995). 
Were there fundamental changes in the treatment of violent men and women by the courts in the course of the period under scrutiny? This question is highly relevant because crime historians generally assume that the number and proportion of violent women in the criminal process decreased in the eighteenth and nineteenth centuries as a result of the long-term process of civilisation. Muchembeld, Spierenburg and Wiener argue that male violent behaviour was increasingly prosecuted in the course of the eighteenth and nineteenth centuries. ${ }^{67}$ The incidence of violent crime became particularly low in the urbanised regions of Europe because there the police force and the civilisation campaigns of charity organisations focussed on male fighting and serious violence. As a result, male violent behaviour - compared to the violent behaviour of women - was increasingly prosecuted, resulting in comparatively lower rates of prosecution for female violent crime. ${ }^{68}$

These trends may be visible in the records of criminal courts which handled more serious violence, but not in the Rotterdam and Amsterdam lower courts, where both male and female violent perpetrators were increasingly prosecuted after ca. 1750. The data of the courts of correction of Amsterdam in the period between 1811 and 1838 show that the number and proportion of female violence increased in the first half of the nineteenth century. Between 1815 and 1835, the number of trials involving women doubled and their proportion to overall crime rose from 15 percent in 1815 to 25 percent in $1835 .{ }^{69}$ Economic decline during that period seems to be the most plausible explanation for the increasing crime rates, although this rise was not related to property crimes, but to violent crime. In 1815 less than 10 percent of the complaints filed against women were related to violence, in 1835 almost 60 percent of the charges against women brought before the court of correction involved violent crime. These accusations included both verbal and physical violence, although 86 percent concerned maltreatment, meaning physical violence. ${ }^{70}$

It is also not likely that the rising figures on male and female violent perpetrators were related to transformations in sentencing and policing. In 1811, the Code Pénal the French criminal law - was introduced, which transformed the judicial system of the Netherlands from a fragmented system with primarily local courts that handled almost all criminal cases into a central system with fewer courts that dealt with specific crimes. The Code Pénal distinguished between various types of crimes: felony cases (crimes), offenses (délits), and less serious offenses (contraventions). From 1811 onwards, regional courts of correction, such as the Amsterdam court of correction, dealt with most of the offenses. Despite these fundamental changes, the data from the correctional court of Amsterdam are to some extent comparable to the Amsterdam criminal courts before 1811 or the early modern correction books (fight books) of Rotterdam. The records of the correctional court hold felony cases (crimes) as well as misdemeanours (délits), just like the old Amsterdam criminal court before 1811 .

67 Wiener (1998); Spierenburg (2008); Muchembled (2012, p. 215).

68 Spierenburg, (2008, pp. 177-178); Muchembled (2012, p. 215).

69 Ruitenbeek argues that the rise in the number and proportion of female crime is not related to demographic developments in Amsterdam during the first of half the nineteenth century. The increasing female crime rates were also not related to economic decline because the number of property crimes decreased while the number of cases of violence increased. Ruitenbeek (2010, p. 67).

70 Ruitenbeek (2010, p. 68). 
Furthermore, Ruitenbeek's study reveals that the figures on female crime rates in the first quarter of the nineteenth century are quite similar to the prosecution trends that can be observed for the seventeenth and eighteenth century. Between ca. 1790 and 1835 women constituted on average 20 percent of those who appeared before the criminal court of Amsterdam. ${ }^{71}$

There is also no evidence of the growing watchfulness of neighbours or public prosecutors regarding male violence in particular. The court cases of Amsterdam suggest that there may have been growing concern from neighbours about fighting and violence, although the greater sensitivity to violence was related to both sexes. Police officers and public prosecutors did not play an active role in the cases brought before the Amsterdam correctional court. Those men and women who were prosecuted for violence by the Amsterdam court of correction were almost always accused by neighbours complaining about fighting, disturbance and noise. ${ }^{72}$

The rise in the proportion of female defendants in Amsterdam may point to an increasing concern about the violent behaviour of women, although such a rise may have been local and more data, covering a longer period of time, would be required to draw such a conclusion. The rise in women's share in violence in Amsterdam may very well reflect a short-term peak. The data for Rotterdam suggest that the proportion of women in violent crime fluctuated strongly; between 1700 and 1800 the proportion of women in the Rotterdam fight books varied between 25 and 44 percent, and there was no long-term decline or rise in women's share in violent crime over the course of this period.

The court cases dealing with violent crime in eighteenth century Rotterdam and nineteenth century Amsterdam are inconsistent with the general historical view on female violence in another way. Spierenburg and others have argued that female violence was directed at other women, rarely at men, and women's motives for using violence against other women usually lay in the sphere of sexual honour. Recently, Warner, Graham and Adlaf have argued that early modern women defined their honour in far broader terms than we have been led to believe. Magistrates' records from the English town of Portsmouth in the years 1653 to 1781 reveal that a reputation for chastity was only one component of what constituted women's honour. Their findings are important because most historians link the high proportion of male violence to the defence of honour, assuming that women were less likely to engage in fighting because they only had to defend their sexual honour. ${ }^{73}$ Their conclusions are confirmed in Tawny Paul's study of eighteenth-century Edinburgh. Paul argues that the received view that female honour was almost entirely about sexual honour needs to be replaced by a more complicated analysis. Thievery or robbery was the second most prominent insult against women of the insult cases brought before the consistory courts of Edinburgh between 1710 and $1770 . .^{74}$

In Amsterdam (1811-1838), many women started a fight to defend their honour because they felt insulted by others, although it was not necessarily their sexual honour they were defending. They were just as much triggered into starting a fight when their financial or economic reputation was at stake. Many women felt offended

\footnotetext{
Heijden, Koningsberger (2013).

72 Ruitenbeek (2010, pp. 68-83).

73 Warner, Graham, Adlaf (2008, p. 296).

74 Paul (2012, pp. 9-13).
} 
because others doubted their financial soundness or because they were accused of theft or bankruptcy. ${ }^{75}$ Apparently, both in Amsterdam and Edinburgh women were fighting about both their sexual and their economic honour. In Amsterdam, female violence was in many cases directed at men: 44 percent of the victims of female aggression were male. Fights generally started with verbal violence and scolding, followed by pulling off of hats or caps and by hitting with the hands, a ladle, pan or broom. ${ }^{76}$ The examination of witnesses reveals that female violence was often very serious; both men and women were seriously injured by the aggression of their female neighbour. It may be tempting to assume that women were mostly violent when acting as the accomplices of male aggressors, but this was not the case in early nineteenth-century Amsterdam. In 67 percent of the cases involving female violent crime, women acted alone without any help from others. ${ }^{77}$

The records of the Rotterdam court of correction (1700-1800) rarely mention honour as an argument for men and women to start a fight. Most violence occurred in the streets and was started for a variety of reasons: annoyance about garbage or noise; disagreement about transactions and money; drunken quarrels in inns about the price of tobacco, wine or beer; accusations of adultery, etc. A good example is that of a landlady from Rotterdam who rented rooms to sailors of the East India Company. In 1750, she was sentenced to a fine of 12 guilders for attacking a male competitor on the quay when they waited for the ships to arrive. ${ }^{78}$ Most male violence began after drinking too much alcohol, and there appeared to be no clear reason for their aggression. For Amsterdam, Spierenburg found that some women imitated typically male types of aggression, for instance by claiming they had been drunk. Only a minority of the women who were tried for violence by the Rotterdam court of correction in the eighteenth century were drunk, and they never used this fact to explain their behaviour. There was another important difference between male and female violence: the use of a weapon. Whereas almost a quarter of the men used a knife to attack their victims, only 10 percent of the violent women used a weapon and when they did, these were typically 'female' weapons such as pottery, dishes, pots and pans. ${ }^{79}$

Finally, the socio-economic background of the men and women who were tried for violence corresponds with the findings of Spierenburg about Amsterdam. Female aggressors belonged to the lower echelons of the working class and lowermiddle classes ${ }^{80}$ The Rotterdam records of the court of correction began to list the defendants' occupation in the course of the eighteenth century; most women were in domestic service, or they worked as needlewomen, cleaners, or seasonal workers, and among them there were many beggars. These women were probably not very different from the violent women found by Spierenburg in Amsterdam. ${ }^{81}$

\footnotetext{
Ruitenbeek (2010, pp. 72-74).

76 Ruitenbeek (2010, p. 78).

77 Ruitenbeek (2010, p. 75).

78 City Archive Rotterdam, Correctional Court of Rotterdam, nr. 270, 10 September 1750.

79 ORA, Vechtboeken 1650-1794, inv.nrs. 266-282.

80 Spierenburg (1997, p. 26).

81 ORA, Vechtboeken, 1700-1795, inv.nrs. 269-282.
} 


\section{PUBLIC OR PRIVATE: A USEFUL DICHOTOMY?}

Do the lower criminal courts of Amsterdam and Rotterdam provide information about the characteristics of female violence, and were there fundamental differences between male and female violence? A central issue in the debate regarding male and female crime relates to the distinction between the public and private sphere, which has been conceptually important to historians of gender and crime ${ }^{82}$. Historians agree that characteristic aspects of male and female roles in social, cultural and economic systems can all be related to a universal structural opposition between the domestic and public domain of activity. ${ }^{83}$ The distinction between private and public spheres has been seen as particularly appropriate to the late eighteenth and early nineteenth centuries when the ideology of separate spheres intensified, although scholars on the early modern period have also adopted this terminology. ${ }^{84}$

Criminologist Malcolm Feeley argues that due to the emergence of a separate private and public sphere - which resulted from the bread winner's ideology which followed industrialisation - women became more confined to the domestic sphere. Consequently, women's actual share in crime decreased, while courts began to treat women's crimes with more leniency. However, historians have found no clear evidence for this assumed link between the emergence of separate spheres and a decline in female violence. ${ }^{85}$ Between 1700 and 1835 there was no decline in the proportion of charges brought against women in the towns of Holland, and the accused women clearly led active lives outside their homes. ${ }^{86}$

In her examination of violence and social order in contemporary Britain, criminologist Jayne Mooney shows that most violence against men currently occurs in public, and most violence against women occurs in private, but in neither instance is the focus overwhelming. ${ }^{87}$ She concludes that violence against men is likely to be more severe in public, while violence against women is likely to be more severe in the private sphere. Furthermore, most male violence in public is aimed at men and male violence against women takes place in the private sphere.$^{88}$ Finally, Mooney's survey reveals that most violence occurs in public, particularly in pubs or other places of entertainment. ${ }^{89}$

On the basis of the data of Spierenburg on the Amsterdam criminal court in the period between 1650 and 1750, the early modern characteristics of female and male violence seem to have been very different from those apparent in the British Crime Survey as presented by Mooney. In Amsterdam, female assault took place as often at home as in a public place, although female killers rarely committed their crime in public. Spierenburg found that in only one of the female homicide files was the scene of crime a public place. ${ }^{90}$ The total file on women tried for non-homicidal

\footnotetext{
Shoemaker (1998, p. 305); Feeley (1994); Arnot, Usborne (2003, p. 23).

Shoemaker (1998, p. 305).

44 Shoemaker (1988, 1991); Spierenburg (1997); Rublack (2002).

85 See King (2008).

86 King (2008); Schwerhoff (2000); Heijden (2013).

87 Mooney (2000, pp. 203-209).

88 Mooney (2000, p. 204).

89 Mooney (2000, p. 201).

$90 \quad$ Spierenburg (1997, pp. 20-22).
} 
violence consists of twenty-five cases. Spierenburg's file on women who committed violence (1650-1750) is based on the criminal records of Amsterdam which dealt with assaults and violence, and this data presumably reveals only a small proportion of female violence. ${ }^{91}$ The number of women tried for violence was much higher in the fight books of Rotterdam (1700-1800) and the correctional court of Amsterdam (1811-1838).

Not only are the numbers divergent, but so are the descriptions of male and female violence. It is surprising to see how much the descriptions of violence in the survey of Mooney about contemporary violence resemble the cases of violence that came before the criminal courts of Rotterdam and Amsterdam between 1700 and $1835 .{ }^{92}$ The fight books of Rotterdam (a total of 6,369 cases) reveal information about the locations of violent acts and it appears that most male and female violence was committed in public (outside the home). Overall, 89 percent of all violence occurred outside the home, although there were slight differences in this respect between men and women. In 95 percent of the cases, female violence occurred in a public space, in particular in the neighbourhood, but also in the streets of other neighbourhoods or in taverns, coffeehouses, wine houses, and inns. In 1760 23-year old Johanna - a migrant from Flanders - was arrested because she started a fight after drinking a bottle of wine in a tavern in Rotterdam. ${ }^{93}$

Only five percent of the women who were tried for violence appear to have displayed violent behaviour in the so-called private sphere, meaning in their home, and such cases were almost always related to infanticide. Some women were sentenced for beating a child, although their violence was never directed at their own child and it occurred in the street. In 1770, for instance, Zwaantje Paardekoper was sentenced to eight days of confinement because she had slapped someone else's child in the street. ${ }^{94}$

Table 6: Male and female violence in public or in private, according to the Rotterdam fight books $1700-1800$

\begin{tabular}{|l|l|l|}
\hline & Men & Women \\
\hline Public & $83 \%$ & $95 \%$ \\
\hline Private & $17 \%$ & $5 \%$ \\
\hline
\end{tabular}

$\mathrm{N}=6.369$

Sources: ORA, Fight books 1700-1795.

Most male violence also took place in public places, although the proportion was slightly lower with 17 percent of violence occurring at home. Male violence at home always involved domestic violence of husbands against their wives, although sometimes children were also involved. Similar to female violence, most male violence took place on the street and in public places of entertainment, although

\footnotetext{
Spierenburg (1997, pp. 16-17).

92 Heijden (1995); Ruitenbeek (2010).

93 City Archive Rotterdam, Correctional Court Records, nr. 271, 2-7 October 1760.

94 ORA, Vechtboek, inv.nr. 277, p.439.
} 
male violence was - more often than female violence - accompanied by alcohol abuse in inns and taverns. ${ }^{95}$

There is no data yet relating to the employment of women who were prosecuted by the Rotterdam correctional courts, but Ruitenbeek provides information about the Amsterdam correctional court cases. She found that the majority of the women who were prosecuted by the Amsterdam correctional courts were employed. Between 1811 and 1835, 62 percent of the female delinquents specified that they had an occupation at the time of their arrest. Furthermore, the women of Amsterdam were increasingly accused and convicted because of violence against their neighbours, and less often because they had committed property offences or moral crimes such as prostitution or adultery. ${ }^{96}$ These figures indicate that dominant household ideologies did not necessarily represent the public activities of men and women. In practice, women's activities transcended the realm of the household. ${ }^{97}$

There may also be a more fundamental problem with regard to the concept of separate private and public spheres. The paradigm of private and public spheres masks the fact that both men and women moved easily between so-called private and public spheres. In his work on gender in early modern England, Shoemaker rightly argues that such contrasts correlate imperfectly with actual gender-role differences. ${ }^{98}$ Historians should make clearer distinctions between the ideologies of the (public) roles of men and women and their actual roles in everyday lives. Dominant household ideologies may have emphasised the non-violent and domestic character of women, in practice women transcended the realm of the household, engaging in criminal activities and violent disputes.

As the data of Rotterdam and Amsterdam between 1700 and 1838 clearly show, both men and women led public lives; within neighbourhoods, on the streets and at markets, in workplaces, churches, places of public entertainment, and through contact with institutions for community facilitation. In many ways and in many places the private lives and public roles of both men and women were very much entwined. Neighbourhoods in particular were places where private and public spheres largely overlapped, and where women had more opportunities to play an active role in quarrels and fights. ${ }^{99}$ Family, work, religion, and neighbourhood did not signify separate spheres, either private or public, but rather blurry spheres in which various private and public interests were mixed.

Eibach suggests that the separation between public and private spheres might be irrelevant for the early modern period because of the blurry notions of private and public. He argues that secular and ecclesiastical authorities meddled as much in what we would now define as private affairs as in public matters. Courts and consistories did not distinguish between public and private violence; they attempted to control violence occurring in the streets as well as in people's homes. The data of Dutch

95 ORA, Vechboek, 1700-1795, inv.nrs. 267-282.

96 Ruitenbeek (2010, pp. 18-19, 45).

97 Heijden, Heuvel (2007); Heijden, Nederveen Meerkerk, Schmidt (2009); Walker (2003).

98 Shoemaker (1988); also Farge (1993). Although touching upon the interactions of private and public lives, and male and female roles in eighteenth-century Paris, Farge does not systematically treat such matters, nor does the book provide much evidence for her argument that male and female roles were much less separate than is often assumed (Garrioch, 1995, pp. 723-724).

99

Heijden (ed.) (2009). 
criminal courts and consistories confirm Eibach's findings, although there is also an important difference between the German and Dutch cases. ${ }^{100}$ While the marriage courts of Germany involved primarily spouses and other family members, in the Dutch courts, neighbours also played a significant role.

\section{WERE DUTCH WOMEN MORE VIOLENT THAN OTHERS?}

Dutch women may appear not to have been fighters if we only consider the common criminal records of Dutch towns, but they certainly do turn out to be fighters when the lower courts of towns are taken into consideration. In Amsterdam and in Rotterdam, the proportion of indicted female crime varied from 20 to 44 percent, and in the vast majority of cases, female violence occurred in a public space. How can we explain such a high proportion of women perpetrators of violent crime in Holland in the early modern period?

The degree of urbanisation is undoubtedly one factor that contributed to women's opportunities for living independent and public lives, and this may have led to higher female rates of violence. The link between high levels of female crime and urbanisation is explored by Beattie in his work on the criminality of women in England. Beattie found women's contribution to crime to be generally much higher in cities than in rural communities or small towns. The lack of economic and social support from the traditional community caused women to lead more independent, public and risky lives. ${ }^{101}$ In his later work Beattie argues that the unusually high level of prosecution of women in London in the period between 1660 and 1750 may be caused by a combination of factors: the migration patterns that resulted in large numbers of women enjoying freedom in towns, the constraints that restricted the lives of most women, and the severe difficulties that many such women experienced in London and that resulted from the irregularity of work and low wages. ${ }^{102}$

Beattie's findings are confirmed by Shoemaker's examination of the London area. Shoemaker argued that because of their public lifestyles and the insecurity of their employment, single women and widows in urban areas were more likely to enter into disputes and less likely to settle their disputes out of court. ${ }^{103}$ Similar conclusions are drawn by Castan and Farge about eighteenth-century rural and urban France. For many young lower-class women migrating from the countryside to the city, criminal activities such as theft, burglary and prostitution became a logical survival strategy. ${ }^{104}$ Lesley Page Moch points to the fact that in eighteenthcentury European cities, migrant women with the least social support "paid for their vulnerability in ways that landed them in jail and saddled them with infants to raise without a husband". ${ }^{105}$

\footnotetext{
100 Eibach (2007, 2011).

101 Beattie (1975, p. 81).

102 Beattie (2001, pp. 63-73).

103 Shoemaker (1991, pp. 207-216, here 209).

104 Beattie (1975, p. 81, 1986); Shoemaker (1991, pp. 208-209); Castan (1980); Farge (1986); Hufton (1974, pp. 278-280).

105 Moch (2003, p. 146).
} 
Shoemaker's study of rural and urban Middlesex adds an interesting angle to the debate on the involvement of women with the law; he not only looked at the involvement of defendants in misdemeanour prosecutions but also at the roles of witnesses and plaintiffs. His studies show that, in early modern England, urban women acted more frequently as witnesses in the church courts and female plaintiffs outnumbered men in urban Middlesex. There appeared to be a vast difference between women in the country, who rarely lodged complaints, and women living in towns. Shoemaker argues that by having a profession or living on their own, the latter were economically less dependent and used the courts and similar institutions with greater frequency and preferred its tougher procedures. In short, they had greater access to justice and they used this access to settle their disputes. ${ }^{106}$ Nonetheless, Shoemaker also concludes that in general women - more than men - faced numerous obstacles when using the judicial system. ${ }^{107}$

The combination of a high degree of urbanisation and a high degree of accessibility to justice may explain why so many women were tried for violence and so many men were prosecuted for domestic violence. The close relationship between the degree of urbanisation and the percentage of female offenders is particularly relevant to the highly urbanised region of Holland. At the end of the eighteenth century, 30 to 40 percent of the Dutch population lived in towns, as opposed to 20 percent in England, 18 percent in Italy, and 5.5 percent in Germany. In Holland (only part of the Netherlands), the level of urbanisation was as high as 70 percent. ${ }^{108}$ Furthermore, the towns in Holland were characterised by an outstandingly high sex ratio. As compared to many other towns in Western Europe, Dutch urban centres, and particularly those in the province of Holland, had very large numbers of women living alone - either permanently or temporarily. ${ }^{109}$

There is not much data about the marital status and the social-economic background of those who were prosecuted by the Dutch courts, though the Rotterdam criminal records (criminal court and correctional courts) certainly indicate that violent women lived independent lives. Between 1700 and 1750 approximately 40 percent of the prosecuted women were migrants who often travelled without parents, a husband or other relatives. Around 40 percent of the women were married at the time of their arrest, though in practice these women appeared to live alone, and they often took care of the children that had resulted from the marriage. In the early modern seafaring towns of Holland, many women were either abandoned by a husband, or they lived independent lives because of the long absence of a seafaring husband. Employees of the East India Company were sometimes absent for ten years or more, and the company rarely informed the wives who stayed behind about the whereabouts of a sailing husband. ${ }^{110}$

The relatively independent position of women and their consequently more important public roles may explain the high rate of female violence in Rotterdam and Amsterdam. ${ }^{111}$ Being involved in public activities, women had more opportunities to

\footnotetext{
106 Shoemaker (1991, p. 211).

107 Shoemaker (1991, p. 318).

108 Vries, Woude (1995, p. 83); Clark (2009, pp. 119-123, 128).

109 Heijden, Heuvel (2007); Heijden (2012).

110 Heijden, Heuvel (2007).

111 Heijden, Heuvel (2007).
} 
make their own decisions, to move around freely, and to work outside the home. This freedom also resulted in greater risks of becoming involved with the law. Because of their more public lifestyle, the insecurity of their employment, and the lack of family support, independent women - especially if they were lower class - were more likely to enter into disputes and to commit violence in times of hardship. ${ }^{12}$ For many young lower-class women migrating from the countryside to the city, criminal activities became a logical survival strategy. ${ }^{113}$

The various opportunities for using justice or other conflict regulation methods may also have contributed to the visibility of Dutch female violence. Whether it concerned male or female perpetrators, most cases of violence were brought before the courts by neighbours who complained about the nuisance, noise and damage. The strong position of Dutch women is also clear from women's own uses of the various judicial options to denounce a husband's domestic violence, and in this respect Dutch women may have differed from women in surrounding countries.

Crucial to Dinges' idea of the uses of justice is the unequal distribution of power resources and spheres of influence among the agents of social control. Women's dependent economic position would discourage battered wives from bringing a husband, as head of the family business, to court. Women, more than men, adhered to other agents of social control, such as family, neighbourhood or extended family. However, this was not entirely true for some parts of early modern Western Europe. ${ }^{114}$ In the German speaking territories women may have faced considerable obstacles when using civil justice, but they did use the ecclesiastical and moreover criminal courts extensively in cases of domestic violence. ${ }^{115}$ According to the compilation of Heinrich R. Schmidt in selected courts of Lutheran, Reformed and Catholic territories between 75 and almost 80 percent of the complaints regarding domestic violence and other domestic dispute were filed by women. Men rarely used these courts to settle conflicts. ${ }^{116}$ As regards the use of criminal courts, Eibach found a lower proportion of female litigants in eighteenth-century Frankfurt. All offences taken together, around 20 percent of the plaintiffs in Frankfurt were women. According to Eibach, however, there were no legal obstacles for women to use the criminal court. ${ }^{117}$

Dutch women may have been reluctant to bring their husband to the criminal courts, but they did make use of other effective options for punishing a husband. As shown, both men and women were quite willing to involve the Protestant consistories in their domestic conflicts, while women - much more than men - made use of the instrument of confinement on request. There seems to have been a mutual dependency between husbands and wives, rather than a one-sided dependency on the part of women, particularly among the social groups that made use of the confinement on request. And this may not be surprising, considering the high labour

\footnotetext{
112 Shoemaker (1991, pp. 208-209).

113 Moch (2003, p. 146).

114 Dinges (2004, p. 167).

115 It must be noted that in the early modern period the distinction between civil and criminal procedures was not always that clear and sometime civil and criminal court cases overlapped.

116 Schmidt (1998, pp. 219-220).

117 Eibach (2002, pp. 75-76).
} 
participation of women, the active and public lives that they led, and the support they were given by neighbours. ${ }^{118}$

The Dutch findings about the support of women seem different to the picture painted by both Beattie and Shoemaker of the greater vulnerability of women in urban areas. However, comparative work on women's crime in other countries and regions is needed to draw firmer conclusions. Without systematic studies on women's crime in rural areas in the Netherlands it is hard to know if such supports were available in small towns or rural areas.

\section{CONCLUSIONS}

What do we learn from the Dutch situation regarding male and female violence in the early modern period? Firstly, looking at male and female violence means looking at different types of courts and institutions dealing with conflict regulation and violence, and examining the ways people used the institutions. The nature of the justice available strongly affects the evidence available about patterns of early modern violence. Comparative research on various courts and forms of conflict regulation reveals how men and women made use of the various forms of justice, and the options men and women had when dealing with violent husbands, neighbours or drunken pub visitors. Women's violent behaviour may remain invisible in the early modern higher criminal court records of Holland, but it becomes more apparent in the records of the lower courts which particularly handled fights and aggression within neighbourhoods.

Secondly, a close inspection of the correctional courts shows that neighbours were quite eager to make use of the accessible correction procedures, and this apparently resulted in high numbers of men and women being tried for violence. A relatively high proportion of trials involved women : in Rotterdam between 1700 and 1800 , on average 35 percent of the fighters were women, and the correctional court of Amsterdam between 1811 and 1835 produced similar figures. The fact that most women in Holland appeared to live rather independent, public and sometimes risky lives may have contributed to higher rates of female violence.

A third conclusion relates to women's recourse to justice in early modern Dutch towns. Whereas Dinges and Shoemaker found that women in German, French and English towns were often faced with various obstacles when using the judicial system, the Dutch judicial system appears to have been more accessible to women, giving them a variety of options for defending themselves against domestic violence. Even if women were reluctant to bring their husbands to court or to request a confinement on request, their neighbours frequently took the initiative to file a complaint against the abusive husbands.

Finally, the paradigm of separate private and public spheres is not adequate for explaining differences between male and female violence. Household ideologies were not necessarily consistent with everyday practices. The records of the correctional courts of Rotterdam and Amsterdam between 1700 and 1835 show that almost all the women who were tried - even more than the men - committed their crimes in public; in the streets in or outside their neighbourhoods, in wine

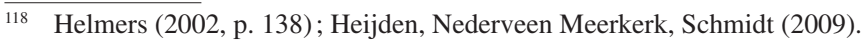


houses, coffee houses and inns. Most of them were working, and did not depend on the income of a husband, father or other relative. Furthermore, family, work and neighbourhood did not involve separate spheres reflecting either private or public activities, but rather blurry spheres in which various interests and activities were mixed. What the various sources on violence perhaps show most clearly is the active involvement of neighbours. Whether violence occurred in the streets, in places of public entertainment, or in the home, it was a communal matter, and neighbours and neighbourhood institutions played a vital role in the prosecution of both public and domestic violence.

Manon van der Heijden

University of Leiden

M.P.C.van.der.Heijden@hum.leidenuniv.nl

\section{REFERENCES}

Arnot, M.L., Usborne, C., Gender and Crime in Modern Europe, London, ULC Press, 1999, [reprinted 2003].

Beattie, J.M., The criminality of women in eighteenth-century England, Journal of Social History, 1975, 8, pp. 80-116.

Beattie, J.M., Policing and punishment in London, 1660-1750: urban crime and the limits of terror, Oxford, Oxford University Press, 2001.

Bekker, M., Huwelijksruzies en handelingsruimte. Rechtsgebruik door gehuwde mannen en vrouwen in Dordrecht, 1750-1800, Unpublished Masters Thesis, University of Leiden, 2012.

Bogaers, L., Aards, betrokken en zelfbewust. De verwevenheid van cultuur en religie in katholiek Utrecht, 1300-1600, Utrecht, Levend Verleden Utrecht, 2008, pp. 65-114.

Burghartz, S., Zeiten der Reinheit - Orte der Unzucht. Ehe und Sexualität in Basel während der Frühen Neuzeit, Paderborn, Schöningh, 1999.

Burke, P., Visualizing neighbourhood in Renaissance Florence: Santo Spirito and Santa Maria del Carmine, Journal of Urban History, 2006, 32, 5, pp. 693-710.

Castan, N., Justice et repression en Languedoc à l'époque des Lumières, Paris, Flammarion, 1980.

Clark, P., European Cities and Towns 400-2000, Cambridge, Cambridge University Press, 2009.

Dean, T., Domestic violence in late-medieval Bologna, Renaissance Studies, 2004a, 18, 4, pp. 527-543.

Dean, T., Gender and insult in an Italian city: Bologna in the later Middle Ages, Social History, 2004b, 29, 2, pp. 217-231.

Dean, T., Theft and Gender in Late Medieval Bologna, Gender \& History, 2008, 20, 2, pp. 399-415.

Deceulaer, H., Implications of the street. Entitlements, duties and conflicts in neighbourhoods in Ghent (17 $18^{\text {th }}{ }^{\text {th }}$ centuries), in Heijden, M. van der (ed.), Serving the Urban Community. The Rise of Public Facilities in the Low Countries, Amsterdam, Aksant Academic Publishers, 2009, pp. 194-216.

Denys, C., The Development of Police Forces in Urban Europe in the Eighteenth Century, Journal of Urban History, 2010, 36, 3, pp. 334-344. 
Descimon, R., Nagle, J., Les quartiers de Paris au Moyen Âge au XVIII ${ }^{\mathrm{e}}$ siècle. Évolution d'un espace plurifonctionnel, Annales 1979, 34, 5, pp. 956-983.

Dinges, M., "Weiblichkeit" in "Männlichkeitsritualen"? Zu weiblichen Taktiken im Ehrenhandel in Paris im 18. Jahrhundert, Francia, 1992, 18, pp. 71-98.

Dinges, M., Der Maurermiester und der Finanzrichter. Ehre, Geld und soziale Kontrolle im Paris des 18. Jahrhunderts, Göttingen, V\&R, 1994.

Dinges, M., The Uses of Justice As a Form of Social Control in Early Modern Europe, in Roodenburg, H., Spierenburg, P. (Eds), Social Control in Europe 1500-1800, Columbus, Ohio State University Press, 2004, pp. 159-175.

Dorren, G., Communities within the community. Aspects of neighbourhood in seventeenthcentury Haarlem, Urban History, 1998, 25, pp. 173-188.

Eibach, J., "Böse Weiber" und "grobe Kerle". Delinquenz, Geschlecht und soziokulturelle Räume in der frühneuzeitlichen Stadt, in Blauert, A., Schwerhoff, G. (Eds), Kriminalitätsgeschichte. Beiträge zur Sozial-und Kulturgeschichte der Vormoderne, Konstanz, UVK, 2000, pp. 669-688.

Eibach, J., Frankfurter Verhöre. Städtische Lebenswelten und Kriminalität im 18. Jahrhundert, Paderborn, Schöningh, 2003.

Eibach, J., Der Kampf um die Hose und die Justiz - Ehekonflikte in Frankfurt im 18. Jahrhundert, in Kesper-Biermann, S., Klippel, D. (Eds), Kriminalität in Mittelalter und Früher Neuzeit: Soziale, rechtliche, philosophische und literarische Aspekte, Wiesbaden, Harrassowitz, 2007, pp. 167-188.

Eibach, J., Das offene Haus. Kommunikative Praxis im sozialen Nahraum der europäischen Frühen Neuzeit, Zeitschrift für historische Forschung, 2011, 38, 4, pp. 621-665.

Eisner, M., Long-term historical trends in violent crime, Crime and Justice. A Review of Research, 2003, 30, pp. 83-142.

Farge, A., Fragile Lives: Violence, Power, and Solidarity in Eighteenth-century Paris, Cambridge, MA., Polity Press, 1993.

Feeley, M., The Decline of Women in the Criminal Process : A Comparative History, Criminal Justice History, 1994, 15, pp. 235-274.

Frijhoff, W., Prak, M. (Eds), Geschiedenis van Amsterdam, Centrum van de wereld 15781650, Amsterdam, SUN, 2004.

Garnot, B., Crime et justice au XVII et XVIII ${ }^{e}$ siècles, Paris, Éditions Imago, 2000.

Garrioch, D., Neighbourhood and community in Paris, 1740-1790, Cambridge, Cambridge University Press, 1986.

Garrioch, D., Book review Arlette Farge, Fragile Lives: Violence, Power, and Solidarity in Eighteenth-century Paris, Cambridge, MA., Polity Press, 1993, The journal of modern history, 1995, 67, 3, pp. 723-724.

Garrioch, D., Peel, M., Introduction: The social history of urban neighbourhoods, Journal of Urban History, 2006, 32, 5, pp. 663-676.

Greenshields, M., Women, violence and criminal justice records in early modern Haute Auvergne (1587-1664), Canadian Journal of History, 1987, 22, pp. 175-194.

Groot, H. de, Inleidinge tot de Hollandsche rechtsgeleerdheid (with notes by S.J. Fockemae Andreae), Arnhem, Gouda Quint, volume I, 1939.

Habermas, R., Frauen und Männer im Kampf um Leib, Ökonomie und Recht. Zur Beziehung der Geschlechter im Frankfurt der Frühen Neuzeit, in van Dülmen, R. (ed.), Dynamik der Tradition, Frankfurt, Fischer, 1992, pp. 109-136.

Haks, D., Huwelijk en gezin in Holland in de $17^{e}$ en $18^{e}$ eeuw, Leiden, Rijksuniversiteit Leiden, 1982. 
Hanawalt, B., Crime and conflict in English communities: 1300-1348, Cambridge, MA., Harvard University Press, 1979.

Heijden, M. van der, Criminaliteit en sekse in $18^{\mathrm{e}}$-eeuws Rotterdam. De verschillen tussen vrouwen en mannencriminaliteit tussen 1700 en 1750, Tijdschrift voor Sociale Geschiedenis, 1995, 21, 1, pp. 1-36.

Heijden, M. van der, Huwelijk in Holland. Stedelijke rechtspraak en kerkelijke tucht 15501700, Amsterdam, Bert Bakker, 1998.

Heijden, M. van der, Women as victims of sexual and domestic violence in 17 th century Criminal cases of rape, incest and maltreatment in Rotterdam and Delft, Journal of Social History, 2000, 33, 3, pp. 623-644.

Heijden, M. van der, Punishment versus Reconciliation: Marriage Control in Sixteenth- and Seventeenth-Century Holland, in Roodenburg, H., Spierenburg, P. (Eds), Social Control in Europe 1500-1800, Columbus, Ohio State University Press, 2004, pp. 55-77.

Heijden, M. van der (ed.), Serving the Urban Community. The Rise of Public Facilities in the Low Countries, Amsterdam, Aksant Academic Publishers, 2009.

Heijden, M. van der, Civic Duty. Public services in the Early Modern Low Countries, Newcastle, Cambridge Scholars Publishing, 2012.

Heijden, M. van der, Heuvel, D. van den, Sailors' families and the urban institutional network in early modern Holland, The History of the Family, 2007, 12, 4, pp. 296-309.

Heijden, M. van der, Koningsberger, V. (2013) Continuity or Change? The Prosecution of Female crime in the 18th and 19th centuries, Crime, Histoire \& Sociétés, Crime, History \& Societies, 2013, 17, 1, pp. 101-127.

Heijden, M. van der, Nederveen Meerkerk, E. Van, Schmidt, A., Terugkeer van het patriarchaat? Vrije vrouwen in de Republiek', Tijdschrift voor Sociale en Economische Geschiedenis, 2009, 6, 3, pp. 26-52.

Helmers, D., "Gecheurde bedde" : oplossingen voor gestrande huwelijken, Amsterdam 17531810, Hilversum, Verloren, 2002.

Hoffmann, C.A., Nachbarschaften als Akteure und Instrumente des soziale Kontrolle in urbanen Gesellschaften des sechzehnten Jahrunderts, in Schilling, H. (ed.), Institutionen, Instrumente und Akteure sozialer Kontrolle und Disziplinierung im frühneuzeitlichen Europa, Frankfurt, Klostermann, 1999, pp. 187-202.

Hoffman, C.A., Social control and the neighborhood in European cities, in Roodenburg, H., Spierenburg, P. (Eds), Social control in Europe, Columbus, Ohio University Press, 2004, pp. 309-327.

Hufton, O.H., The poor of eighteenth-century France, 1750-1789, Oxford, Clarendon Press, 1974.

Joor, J., Echtscheiding en scheiding van tafel en bed in Alkmaar in de periode 1700-1810, Tijdschrift voor Sociale Geschiedenis, 1985, 11, pp. 197-230.

Kilday, A.-M., Women and Violent Crime in Enlightment Scotland, Woodbridge, Suffolk, Boydell Press, 2007.

King, P., Crime and the Law in England, 1750-1840, Cambridge, Cambridge University Press, 2006 [reprinted 2008].

Kloek, E., Wie, hij zij, man of wijf. Vrouwengeschiedenis en de vreogmoderne tijd, Hilversum, Verloren, 1990.

Kuipers, E., Migrantenstad. Immigratie en sociale verhoudingen in $17^{e}$-eeuws Amsterdam, Hilversum, Verloren, 2005.

Lis, C., Soly, H., Neighbourhood social change in West European cities. Sixteenth to nineteenth centuries, International Review of Social History, 1993, 38, pp. 1-30.

Meeteren, A. van, Op hoop van akkoord. Instrumenteel forumgebruik bij geschilbeslechting in Leiden in de zeventiende eeuw, Hilversum, Verloren, 2006. 
Moch, L.P., Moving Europeans. Migration in Western Europe since 1650, Bloomington, Indiana University Press, 2003.

Mooney, J., Gender, violence and the social order, Basingstoke, Macmillan, 2000.

Morris, A., Women, Crime and Criminal Justice, Oxford, Blackwell, 1987.

Muchembled, R., A History of Violence, Cambridge, Polity, 2012.

Paul, K.T., Credit, reputation, and masculinity in British urban commerce: Edinburgh, c. 1710-70, Economic History Review, 2012, pp. 1-22.

Pol, L. van de, Het Amsterdams hoerdom. Prostitutie in de zeventiende en achttiende eeuw, Amsterdam, Wereldbibliotheek, 1996.

Pollmann, J., Off the Record: Problems in the Quantification of Calvinist Church Discipline, Sixteenth Century Journal, 2002, 33, 2, pp. 423-438.

Roodenburg, H., Naar een etnografie van de vroegmoderne stad. De 'gebuyrten' in Leiden en Den Haag, in Boekhorst, P.T., Burke, P., Frijhoff, W. (Eds), Cultuur en maatschappij in Nederland, 1500-1850. Een historisch-antropologisch perspectief, Meppel-Amsterdam, Open Universiteit, 1992, pp. 219-243.

Rostenthal, D., Big P., the Empire of the Meadow, and the Parish of Santa-Lucia: Claming Neighbourhood in the Early Modern City, Journal of Urban History, 2006, 32, 5, pp. 677692.

Rublack, U., The crimes of women in early modern Germany, Oxford, Oxford University Press, 1999.

Rublack, U. (ed.), Gender in Early Modern German History, Cambridge, Cambridge University Press, 2002.

Ruitenbeek, O., "Hem - de waereld, haar - het huis"? De intrede van het huiselijkheidsideaal onder Amsterdamse volksvrouwen 1811-1838, Master Thesis Universiteit Amsterdam, 2009.

Ruitenbeek, O., Niet zonder kleerscheuren. Criminaliteitspatroon, eergevoel en het gebruik van fysiek geweld door Amsterdamse volksvrouwen (1811-1838), Amstelodamum, 2010, 102, pp. 62-85.

Schmidt, H.R., Hausväter vor Gericht. Der Patriarchalismus als zweischneidiges Schwert, in Dinges, M. (ed.), Hausväter, Priester, Kastraten. Zur Konstruktion van Männlichkeit in Spätmittelalter und Früher Neuzeit, Göttingen, V\&R, 1998, pp. 213-236.

Schwerhoff, G., Gender and Criminal Justice: the German Case [paper 19th International Congress of Historical Sciences, 6-13 August, Oslo], 2000.

Schwerhoff, G., Social Control of Violence, Violence As Social Control: The Case of Early Modern Germany, in Roodenburg, H., Spierenburg, P. (Eds), Social Control in Europe 1500-1800, Columbus, Ohio State University Press, 2004, pp. 220-246.

Shoemaker, R., Gender in English Society 1650-1850. The Emergence of Separate Spheres, London, Longman, 1988.

Shoemaker, R., Prosecution and punishment. Petty crime and the Law in London and rural Middlesex, c. 1660-1725, Cambridge, Cambridge University Press, 1991.

Spierenburg, P., The prison experience. Disciplinary institutions and their inmates in early modern Europe, Amsterdam, Amsterdam University Press, 1991.

Spierenburg, P., Zwarte schapen: losbollen, dronkaards en levensgenieters in achttiendeeeuwse beterhuizen, Hilversum, Verloren, 1995.

Spierenburg, P., Long-term trends in homicide. Theoretical reflections and Dutch evidence, fifteenth to twentieth centuries, in Johnson, E.A., Monkkonen, E.H. (Eds), The civilization of crime. Violence in town and country since the Middle Ages, Urbana, Chigaco, 1996, pp. 63-105. 
Spierenburg, P., How violent were women? Court cases in Amsterdam, 1650-1810, Crime, Histoire et Sociétés/Crime, History \& Societies, 1997, 1, 1, pp. 9-28.

Spierenburg, P., A History of Murder. Personal Violence from the Middle Ages to the Present, Cambridge, Polity, 2008.

Vries, J., Woude, A. van der, Nederland 1500-1815 : de eerste ronde van moderne economische groei, Amsterdam, Balans, 1995.

Walker, G., Crime, gender and social order in early modern England, Cambridge, Cambridge University Press, 2003.

Walle, K., Buurthouden De geschiedenis van burengebruiken en buurtorganisaties in Leiden (14 $-19^{e}$ eeuw), Leiden, Ginkgo, 2005.

Warner, J., Graham, K., Adlaf, E., Women Behaving Badly: Gender and Aggression in a Military Town, 1653-1781, Sex roles: a journal of research, 2005, 52, 5/6, pp. 289-299.

Warner, J.; Riviere, J., Graham, K., Men and Women Fighting Side By Side: Examples From an English Town, 1653-1781, Journal of Family History, 2008, 33, 3, pp. 156-172.

Wiener, M., The Victorian criminalization of men, in Spierenburg, P. (ed.), Men and violence: gender, honor and rituals in modern Europe and America, Columbus, Ohio University Press, 1998, pp. 197-212. 